Zuzana Bednarikova', Miroslava Bavorova ${ }^{2}$, Elena Ponkina ${ }^{3}$

\author{
${ }^{1}$ Purdue University \\ ${ }^{2}$ Czech University of Life Sciences \\ ${ }^{3}$ Altai State University \\ ${ }^{1} U S A$ \\ ${ }^{2}$ Czech Republic \\ ${ }^{3}$ Russia
}

\title{
ENTREPRENEURIAL INTENTION OF AGRICULTURE UNDERGRADUATES IN RUSSIA
}

Purpose. This paper aimed to investigate factors that influence the intention of educated youth in remote areas of Siberia to start-up business under the specific conditions with postcommunist legacy. Special attention is paid to the willingness of graduates to run a business in agriculture.

Methodology / approach. We surveyed 470 university students and applied logistic regression to analyze the probability of becoming self-employed.

Results. Study results reveal that being male, an existing family entrepreneurial tradition, and effort of respondents to increase their quality of life, such as a desire for a higher income and career efforts, improve the intention to be self-employed. Preference to live in rural areas decreases the entrepreneurial intention. We identified an important path dependency problem that arises from the low entrepreneurial literacy and tradition of the families because setting up a private business is a novelty in Russia.

Originality / scientific novelty. The Global Entrepreneurial Monitor Review ranks Russia among countries with the lowest entrepreneurial intention. This fact may threaten the development of the country as self-employment represents an important trigger for the economic development of a region, especially for its rural and remote part. Entrepreneurs in agriculture might help in recultivation of the abandoned land in Russian Siberia if the entrepreneurial education and incentives were set properly.

Practical value / implications. A promotion of entrepreneurship education at the universities, removing administrative barriers to business development, and launching programs to support young entrepreneurs, especially in rural areas, might be crucial in increasing the entrepreneurial activity of youth. This study has important implications for policymakers and education system as youth entrepreneurship provides an opportunity to decrease unemployment, ensure the income of the rural population, and promote sustainable growth of rural areas.

Key words: entrepreneurial intention, rural areas, agriculture, youth, logit regression, Russia.

Introduction and review of literature. Entrepreneurship is one of the determinants of economic growth (Audretsch and Thurik, 2000), and the creation of small and medium-sized enterprises, especially in the secondary and tertiary sectors, can resolve problems induced by the changes in agriculture (Stathopoulos et al., 2004). Many remote rural areas throughout the world, including Russian Siberia, could be characterized by depopulation, infrastructural inadequacies, and a high 


\section{Agricultural and Resource Economics}

www.are-journal.com

dependence on agriculture. In these areas, the need for economic diversification and integrated development is stronger than in conventional rural areas. On the one hand, changes in agriculture (primarily technological progress) are expected to reduce employment opportunities in farming. On the other hand, rural areas offer real opportunities, such as food processing diversification driven by increased demand for quality products from the food and light manufacturing sectors, and recreation (Stathopoulos et al., 2004). Further, as the problem of land abandonment is prevalent in the area, scarcity of land is not a significant factor preventing the establishment of new agricultural businesses.

The latest Global Entrepreneurial Monitor Review ranks Russia last among 70 countries in terms of entrepreneurial intention, with only $3.5 \%$ of respondents being willing to start a business (GEM, 2014). Kiryushin (2011) mentions even lower statistics, with only $2 \%$ of the Russian population wanting to establish their own business. Our research is motivated by the fact that young agricultural graduates possibly represent a large and very well qualified reservoir of entrepreneurs in rural areas. These young people may be expected to work in agriculture or related sectors such as food processing or tourism, but the question is whether they would like to establish and run their own business.

Over the years during the Soviet era, the dominant ideology has been firmly formed in a disbelieving cautious attitude to everything non-governmental such as establishing own business. The new generation born or growing up after the collapse of the Soviet Union, however, does not seem to inherit this opinion, and the proportion of youths who aspire to establish their own business is quite high (Kasyanov, 2011). Understanding factors that influence and shape the intention of young educated people to start-up business in the future is critical for the encouragement of youth entrepreneurial behavior.

In 'transition economies' including Russia, knowledge of the development of a private sector is rudimentary, and only a few studies exist that use a rigorous scientific approach on self-employment intention among Russian students (see e. g. Åslund, 2012; Tkachev and Kolvereid, 1999). There is also a lack of research in the field of graduate entrepreneurship in countries with developing economies (Ghulam and Liñán, 2011; Iakovleva et al., 2011). This research may help to understand these issues considering graduate entrepreneurial intentions, business start-ups, and education, especially in developing economies in post-communist countries.

The main objective of our research is to close this gap and to explore and analyze factors that influence the entrepreneurial intention of educated youth. To achieve this objective, we use a sample of 470 graduate students of the Altai State Agricultural University in Barnaul collected in 2016. Rural areas of Altai Krai represent a breadbasket of Siberia, and farming is one of the primary sources of employment opportunities and income. Using a logit regression analysis, we analyzed the factors that are supposed, based on the literature review and local conditions, to affect the entrepreneurial intention. These factors are gender, education, entrepreneurial family roots, place of origin, migration intention, attraction to rural 


\section{Agricultural and Resource Economics}

www.are-journal.com

life, attitude towards the business establishment, and, finally, the importance of salary and career, and perception about leading a meaningful life.

This paper contributes to a growing number of studies that focus on graduate's thinking before they transition from education to the labor market or entrepreneurship (see, e.g., Oinonen, 2018; Unay-Gailhard, 2016; Nabi et al., 2010). Even though a gap between self-employment intentions and de facto self-employment among graduates may exist, the presented study has the potential to improve the understanding of factors that might influence a willingness of graduates to establish own business.

Factors of Entrepreneurial Intention. Based on the previous studies and conditions in the rural areas of Altai Krai, we identified three groups of factors that might have a bearing on the intention of the agriculturally educated youth to establish their own business: personal and family background, rurality, and quality of life.

Personal and Family Background. Considering the role of gender, the malefemale differential in self-employment has remained almost unchanged over time (Arenius and Kovalainen, 2006). It is traditionally assumed that women have a lower inclination towards self-employment than men. Many studies have found a substantial overrepresentation of males among business founders in most countries (Scherer et al., 1990; Davidson, 1995; Carter et al., 1997). Scherer et al. (1990) refer to lower perceptions of self-efficacy for careers in which they are underrepresented.

Education may provide the incentive for self-employment and the ability to establish a business. As a result, higher education should have a positive effect on self-employment (Mueller, 2006). The study by Autio et al. (1997) indicates that the image of encouragement from a university environment and the image of entrepreneurs affect the entrepreneurial intention of university students. Turker and Selcuk (2008) find that a supportive university environment mainly indicates educational support. If a university provides adequate inspiration and knowledge of entrepreneurship, the likelihood of choosing a career as an entrepreneur may increase among young people in Turkey. Thus, education plays a crucial role in entrepreneurial conviction. Naudé et al. (2008) emphasize that start-up activity in a region increase when nascent entrepreneurs are better educated than average.

The family background may affect the intention to become an entrepreneur in various ways. The study by Scott and Twomey (1988) analyses the intentions of university students, and the results identify that respondents whose parents own a small business show a higher preference for self-employment and a decreased preference for employment in a large business. The studies by Davidson (1995) refer to the positive relationship between self-employed parents and the intention to establish a small business by their child. Ljubotina et al. (2019) pointed out the vital role of work experience in a family business. The family financial support helps the young entrepreneur to overcome capital market voids (Manolova et al., 2019). The link between the parental role and preferences for entrepreneurship is demonstrated in the study by Matthews and Moser (1995), which finds that women with entrepreneurial parents convey greater interest in self-employment than women 


\section{Agricultural and Resource Economics}

www.are-journal.com

without such vicarious experience. Strong family ties can help young people to overcome entrance barriers to self-employment, by providing them access to valuable resources, such as access to the social networks of their parents (Edelman et al., 2016). Laspita et al. (2012) find that the strength of parental influence on the entrepreneurial intentions of their children depends on when and for how long the parents have been entrepreneurs. The parental impact is significant when they have been entrepreneurs during the adolescence of the young person but is insignificant when they have been entrepreneurs during the relevant person's childhood.

Rurality. Rurality offers an innovative and entrepreneurial environment in which enterprises may prosper or become suppressed. Stathopoulou et al. (2004) report that rurality and the entrepreneurial process form a dense, complex, and dynamic network of mutual influences. This environment significantly affects individual behavior. In the entrepreneurial context, Kibler (2013) mentions that individuals believe in the presence or absence of requisite capabilities and resources for performing a given behavior. The more an individual believes in his or her ability to successfully start and run a business, the stronger should be the intention of the individual to become an entrepreneur.

In our analysis, we considered the effect of rurality on students' intention to create their businesses. For this purpose, we tested the impact of the following independent variables in the regression model: the respondent's perception of difficulty to create an own business in the parental municipality, the migration intention, and the attraction to a rural way of life.

Quality of life. In this study, we pay attention to the factors of quality of life that may influence entrepreneurial decisions. Noorderhaven et al. (2004) point out that countries with lower overall life satisfaction of the inhabitants have a higher proportion of self-employed than those with higher life satisfaction. Thus, if more people in a country feel dissatisfied with their lives, this increases the chance that they will seek self-employment. Within this context, Noorderhaven et al. (2004) consider economic variables that can influence dissatisfaction with life, such as the level of economic development (prosperity) measured by per capita income, unemployment, and earnings differentials. Other studies show that opportunity and work experience increase the entrepreneurial propensity (Turker et al., 2005; Wand and Wong, 2004). Unemployment and high profits serve as push factors for entering self-employment (Evans and Leighton, 1990). Earning differentials between salaryemployment and self-employment and the subsequent potential benefit may be an apparent reason for establishing a business or for shifting from salary-employment to self-employment. However, an individual must take into account the possible risks connected with running a business. To consider the economic factors, in this study, we tested the importance of salary level, as well as career opportunities for respondents, and their effect on the intention to become entrepreneurs.

Other authors (e.g., Hemmasi and Prorok, 2002; Bakulina and Chernish, 2016) note that quality of life is greatly affected by the socioeconomic characteristics of a community. They refer to rural inhabitants, who often lack access to adequate 


\section{Agricultural and Resource Economics}

www.are-journal.com

employment, education and health opportunities and suffer from inadequate social and technological amenities. The environment of the individual, personal, and other factors may influence satisfaction with life in general. Based on this prediction, we assessed how the perception to lead a purposeful and meaningful life affects the intention to run a business.

The purpose of the article. This paper aimed to investigate factors that influence the intention of educated youth in remote areas of Siberia to start-up business under the specific conditions with post-communist legacy. Special attention is paid to the willingness of graduates to run a business in agriculture.

Study Area. We collected data at the Altai State Agricultural University (ASAU) in Barnaul, the only agricultural university in Altai Krai. Altai Krai is in the southeast part of western Siberia (Fig. 1) and represents a typical agrarian region in Russia, with agriculture as the key element of the regional economy. Ministry of Education and Science of the Russian Federation in 2014 reported the low entrepreneurial activities of young people in Altai Krai. Graduates of high schools and universities in Altai Krai ranked in 56th place among the 83 Russian regions, with only $2.7 \%$ of graduates establishing their businesses after completing their university studies (the Kabardino-Balkan Republic occupies 1st place with $6.3 \%$ ). The highest share of monitored graduates in Altai Krai to become self-employed is from the ASAU (4\%) (Ministry of Education and Science, 2014), the university where our research was conducted.

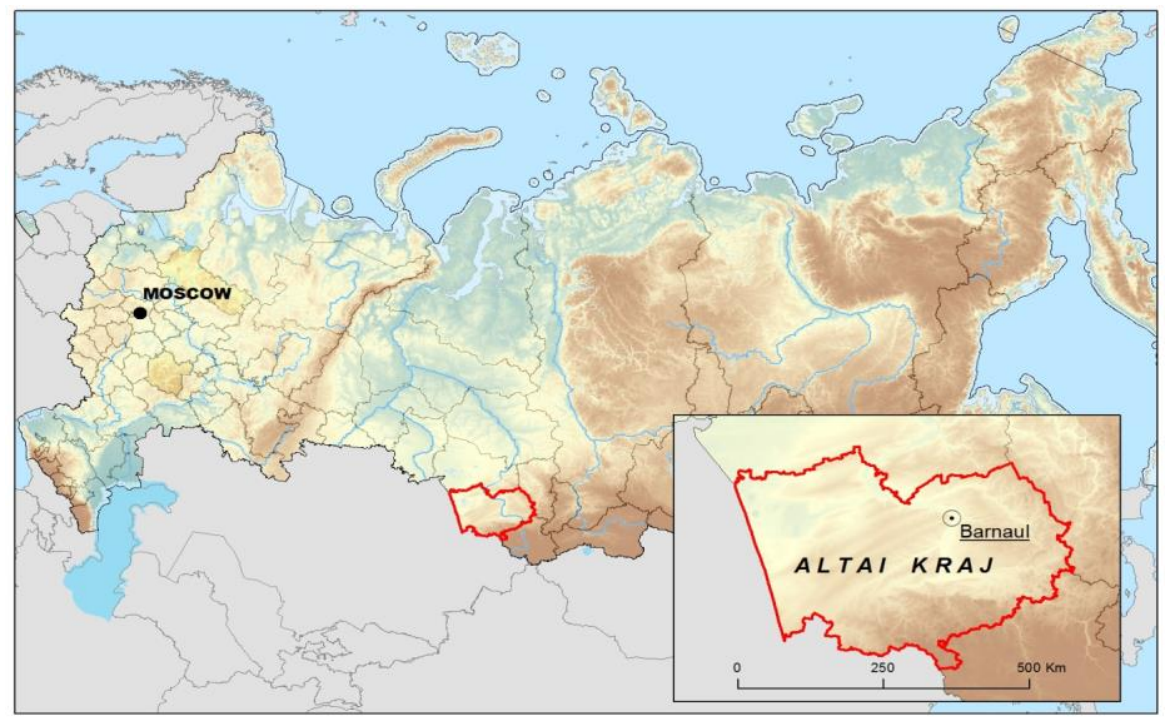

Fig. 1. Position of Altai Krai within the Russian territory

Source: Alexander Prishchepov.

Similar to the whole of Russia, many obstacles that discourage potentially interested people from establishing a business are also evident in this region. The potential of small enterprises is underutilized. Even though they have great potential for creating new jobs, enhancing employment, and maintaining the material wellbeing of citizens.

Reduction in agricultural production as a result of the multi-year period of transformation of the entire economic complex resulted in the spread of negative 


\section{Agricultural and Resource Economics}

www.are-journal.com

social phenomena, such as mass unemployment, poverty, limited access to education, culture, housing, and medical care for villagers. These, in general, gave rise to social and psychological maladjustment, moral and cultural degradation of villagers, and, consequently, a high migration of young people and specialists from rural areas (Kovalenko, 2012; Sergienko et al., 2013). In Russia, life in rural areas has always been closely connected with subsistence farming, the most common form of selfemployment for the rural population (Kalugina, 2014). This tradition continued after the collapse of the Soviet Union. In the 1990s, western observers anticipated the destruction of the collectivized system and the emergence of family farming and commercial households, as a result of post-Soviet agrarian reforms (Ellman, 2003). Instead, the unexpected growth of production on small household plots occurred. Kalugina (2014) mentions that subsistence farming has become the only area of employment and a significant source of income for many rural inhabitants after the collapse of collective farming. According to the statistics, $99.1 \%$ of rural households consider food self-sufficiency as the primary purpose of their farming activities. This situation partially defeated poverty and unemployment, but also reflects the low level of self-employment in agriculture, as subsistence farming represents the primary source of income for only $0.7 \%$ households in Russia (Rosstat, 2007) and $6 \%$ of households in Altai Krai (Sergienko et al., 2013). Subsistence farming usually does not provide an attractive field of work for university graduates.

Methodology. Data collection. Data for the study were collected by a standardized pen-and-paper survey at the ASAU in Barnaul. Barnaul is an important regional center of scientific development where eight state and four private universities are located. The ASAU is a Federal-State budgetary educational institution established in 1943 that serves nearly 3,600 full-time students.

Agricultural students represent the primary and most qualified resource for potential entrepreneurs in agriculture and related sectors, with the likelihood that they will establish their businesses in rural areas. The questionnaires were handed out to full-time students in their 4th and 5th years at the ASAU, before the beginning of their classes. Three study groups of students were interviewed in their 4th year and three groups in their 5th year. At this age, students are considered as being able to form an idea about their future lives and future careers as employees or entrepreneurs. They are also experienced in the urban lifestyle and its opportunities, challenges, and threats.

A pre-test survey was conducted among 15 students to ensure that students understood the questionnaire. The purpose of the study and the rules for completing the questionnaire were explained to the students before they began completing the surveys. The survey was anonymous, and the co-author was present during the data collection. The average time taken to complete a questionnaire was 15 minutes. Data collection started in May 2016, when 200 questionnaires were distributed and collected. An additional 300 questionnaires were distributed and collected in September and October 2016. Finally, a total of 500 students filled out the survey. Valid questionnaires were obtained from 470 students from Altai Krai (450 


\section{Agricultural and Resource Economics \\ www.are-journal.com}

respondents originating from 178 municipalities) and the neighboring Altai Republic (20 respondents), which does not have an agricultural university (see Figure 2).

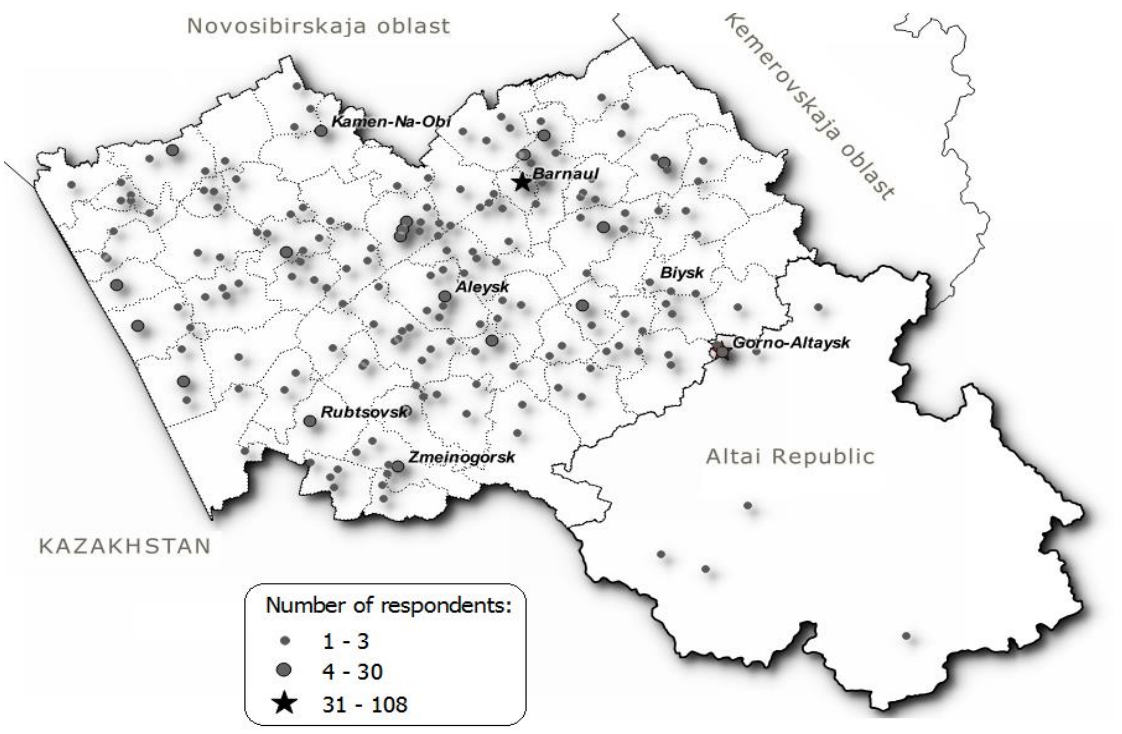

Fig. 2. Respondents' parental municipalities in Altai Krai and the Altai Republic $(\mathrm{N}=470)$

Source: author's research.

Data analysis. We applied a logistic regression analysis, which analyses the probability of becoming self-employed. Logit regression analysis is often used in studies related to the decision whether to become an employee or self-employed (e.g., Arenius and Kovalainen, 2006; Lehberger and Hirschauer, 2015; Noorderhaven et al., 2004; Tkachev and Kolvereid, 1999; Poon et al., 2012). Similarly, in this study, we examined the factors that were supposed to explain the intention to establish a business.

For this study, we were interested in students who had developed an intention to become self-employed. Our dependent variable was a binary measure $(1=$ Yes, $0=$ No) and was derived based on the responses to the question on the students' intention to run a business. According to this variable, 175 students indicated their intention to establish their businesses. We examined the factors - independent variables - that predicted the plans to run their business in different sectors, with a particular focus on agriculture. The variables and their scales included in the logit regression analysis are presented in Table A.1.

Results and discussion. Table 1 summarises the results of the logit model addressing self-employment decisions. Our results show that $37 \%$ of the respondents reported a desire to be self-employed. Our results indicate the enthusiasm of students during their period of study. Reality interferes with students' desire to establish their businesses after graduating from university. The business environment for the establishment of a company has deteriorated in recent years in Russia as a whole. A survey carried out among Russian entrepreneurs in 2015 presents the main factors causing this situation: an increase of prices and tariffs (56.6\% of respondents), high taxes $(43.6 \%)$, a shortage of qualified staff $(40.4 \%)$, a decrease of credit availability 
www.are-journal.com

(36.5\%), high administrative barriers (23.1\%), and corruption (23\%) (RSPP, 2016).

Table 1

Logistic regression of agricultural university students' intention to establish its own business, Altai Krai, Russia

\begin{tabular}{|c|c|c|c|c|c|}
\hline Indicators & Coef. & Std. Err. & $\begin{array}{l}\text { Odds } \\
\text { Ratio }\end{array}$ & \multicolumn{2}{|c|}{$\begin{array}{c}95 \% \\
\text { Conf. Interval }\end{array}$} \\
\hline \multicolumn{6}{|l|}{ Personal and family background } \\
\hline Gender & $-0.447 * *$ & 0.222 & 0.640 & -0.882 & -0.011 \\
\hline $\begin{array}{l}\text { Father's education (university degree } \\
\text { or not) }\end{array}$ & 0.053 & 0.256 & 1.054 & -0.450 & -0.556 \\
\hline $\begin{array}{l}\text { Mother's education (university degree } \\
\text { or not) }\end{array}$ & $-0.419 *$ & 0.241 & 0.658 & -0.891 & 0.054 \\
\hline $\begin{array}{l}\text { Father's employment status (self- } \\
\text { employed or not) }\end{array}$ & $0.963 * * *$ & 0.293 & 2.620 & 0.389 & 1.537 \\
\hline $\begin{array}{l}\text { Mother's employment status (self- } \\
\text { employed or not) }\end{array}$ & 0.296 & 0.379 & 1.345 & -0.447 & 1.040 \\
\hline Parents expect support & $0.391 * * *$ & 0.147 & 1.48 & 0.104 & 0.679 \\
\hline \multicolumn{6}{|l|}{ Rurality } \\
\hline Difficulty to create business & $0.517 * * *$ & 0.177 & 1.676 & 0.170 & 0.863 \\
\hline Place of origin & $1.585 * *$ & 0.793 & 4.882 & 0.031 & 3.142 \\
\hline Migration intention & $0.456 * * *$ & 0.155 & 1.578 & 0.153 & 0.759 \\
\hline Migration intention_urban $^{1}$ & -0.402 & 0.258 & 0.669 & -0.909 & 0.104 \\
\hline Attracted to rural life & $-0.304 *$ & 0.183 & 0.738 & -0.663 & -0.055 \\
\hline \multicolumn{6}{|l|}{ Quality of life } \\
\hline Importance of wage level & $-0.393 *$ & 0.206 & 0.675 & -0.797 & 0.011 \\
\hline Importance of carrier opportunities & $0.598 * * *$ & 0.201 & 1.819 & 0.205 & 0.992 \\
\hline Lead a meaningful life & $0.390 * *$ & 0.158 & 1.477 & 0.080 & 0.700 \\
\hline Constant & -5.148 & 1.323 & 0.006 & -7.742 & -2.555 \\
\hline
\end{tabular}

Note: $\mathrm{N}=466 ; \mathrm{R}^{2}=0.113$.

1 interaction term

$*$ p-value $<0.1 ; *$ p-value $<0.05 ; * * *$ p-value $<0.01$.

Source: author's calculations.

Personal and family background. Results of the regression analysis show that being male increases the probability of creating their own business. This is not an unexpected outcome, and many studies have come to the same conclusions (see, e.g., Davidson, 1995; Scherer et al., 1990).

Nonetheless, changes in Russian society are reflected in the descriptive statistics, with a relatively large proportion of our female respondents (35\% from all female respondents) reporting the intention to be self-employed (Table 3). This result corresponds with modern trends that entrepreneurship has become more popular among women (see, e.g., Turker and Selcuk, 2008; Arenius and Kovalainen, 2006; Boden, 1999). The image of the 'working mother" started in the Soviet period as the double burden of full-time paid work and domestic care duties. Women in the Russian labor market preserve their presence in the labor force, and the labor market is characterized by intense gender segregation (Kozina, 2005). There is proof that Russian women have only minimal options for attaining leading positions in industry, 


\section{Agricultural and Resource Economics \\ www.are-journal.com}

politics, or other spheres of social enterprise. This fact, together with the high unemployment, attracts women to entrepreneurship (Ylinenpää and Chechurina, 2000). Several factors motivate women to launch small businesses. Research carried out by Ylinenpää and Chechurina (2000) shows that the most significant motives are related to material elements. These authors explain this result by economic problems, especially in rural areas, and by the effort to catch up with Western economies in terms of material standards of living. On average, Russian women earn approximately one-third less than men. Entrepreneurial activities offer greater flexibility in combining work and family responsibilities than paid jobs. In many rural areas, male-dominated industrial branches are prevalent.

Women in Russia establish small-scale businesses that represent branches of the tertiary sector, such as childcare and healthcare, education, sewing clothes, knitting, handicrafts, and retail trade (Sätre, 2010). Our female respondents also reported their preferences for running their businesses in trade and services or other sectors outside of agriculture and manufacturing, as shown in Table 2. Sergienko et al. (2013) argue that women often replace men and support the family because men are unemployed, have low-paying jobs, or are paid in kind. This situation increases the economic activities of women and motivates them to become entrepreneurs. Sätre (2010) also hypothesizes that women start-up businesses, because they believe it is the only way of supporting themselves and that they trust their networks.

Table 2

\section{Entrepreneurial intentions of 470 students at the State Agrarian University} in Barnaul, Russia

\begin{tabular}{|c|c|c|c|c|}
\hline \multirow{2}{*}{$\begin{array}{c}\text { The sector of employment or } \\
\text { entrepreneurship }\end{array}$} & \multicolumn{2}{|c|}{$\begin{array}{c}\text { Employment } \\
\% \text { (number) }\end{array}$} & \multicolumn{2}{|c|}{$\begin{array}{c}\text { Own business } \\
\% \text { (number) }\end{array}$} \\
\hline & Male & Female & Male & Female \\
\hline Total/according to gender & $60 \%(112)$ & $65 \%(183)$ & $40 \%(76)$ & $35 \%(99)$ \\
\hline \multicolumn{5}{|c|}{ Of which $(\%)$} \\
\hline Agriculture & 33 & 14 & 25 & 12 \\
\hline Manufacturing & 21 & 26 & 16 & 8 \\
\hline Wholesale \& retail trade & 6 & 7 & 12 & 18 \\
\hline Services & 8 & 19 & 18 & 30 \\
\hline Others & 32 & 34 & 29 & 31 \\
\hline
\end{tabular}

Note: Sample of 282 female and 188 male respondents.

Source: author's calculations.

Our results show no significant effect of a father's education on selfemployment intention. On the other hand, having a mother with a university degree decreases the probability that her child will establish a business. It can be explained by the fact that the mother serves as an example that people with higher education may have better opportunities for finding a relevant job as an employee. This is related mainly to students coming from the urban areas of Altai Krai. $51.5 \%$ of urban students have mothers with a university degree, compared to $36.5 \%$ of rural students' mothers. Moreover, most mothers of the respondents are employees. Kalugina (2014) mentions that salaries continue to be the primary source of income for Russian inhabitants. One can expect that children of employed parents, especially working 


\section{Agricultural and Resource Economics}

www.are-journal.com

mothers, perceive this status of employment as more familiar.

Our model confirms that respondents whose fathers run their businesses are more interested in becoming entrepreneurs. However, no effect can be found for having a self-employed mother. The desire to follow in the family path as a key factor behind the decision whether to be self-employed is twofold. The fact that most parents, mainly urban, highly educated mothers, are employed, may indicate the importance of education for finding a good job and decrease the entrepreneurial intention of university students. On the other hand, having a self-employed father enables a sharing of experience and may raise the perception that it is not difficult to establish a firm. These factors increase the propensity to develop a business or to continue as a successor in the family business. This role model of a self-employed father is particularly essential, as family traditions in entrepreneurship do not have a long history, typical for a post-socialist economy. Besides, Russia is a society with distinct patriarchal traditions and features.

Because our cohort consists of agricultural students, we tested the willingness of students to establish their businesses in agriculture. Only 30 students reported their desire to be entrepreneurs in agriculture. Sätre (2010) mentions that people in Russia seem reluctant to invest in small businesses in agriculture and manufacturing. Also, it is presumably more comfortable to set up small enterprises within trade and services for those who lack investment resources. From this point of view, our research showed the importance of family ownership of agricultural land.

In the 2000s, small-scale household plots became the leading sector within the agrarian economy (Kalugina, 2014). The ownership of agricultural land motivates the owners to establish an agricultural business. Nevertheless, we also must point out that only $13 \%$ of self-employed fathers of our respondents run their agricultural businesses. Utsch et al. (1999) emphasize the non-existence of family traditions in post-Soviet countries to become entrepreneurs, or of any ready-made structure received from the family. Sutherland (2010) remarks on the essential elements affecting the decision not to establish a business in agriculture. Parents desire that their children obtain employment outside of agriculture, which is perceived to be less arduous and higher paid. Many Russian farmers do not anticipate family succession. The higher level of reluctance towards succession appears to be due to a lack of government support.

Another element is the high rate of failure of private farmers in Russia, indicating that farm establishment is a high risk, even with informal connections helping to access land. In this context, it is not surprising that only a few students plan to continue in their parental footsteps to carry on agricultural business.

Parental expectations to be supported financially in the future increase the intention of their children's willingness to become entrepreneurs. The explanation of this result could be in the notion of our respondents that being self-employed provides better opportunities for higher earnings. It might be challenging to manage the burden of parents' financial support from an employee's salary, as the average monthly salary in Altai Krai in 2016 was 20,873 roubles (GKS, 2016). 


\section{Agricultural and Resource Economics}

www.are-journal.com

Rurality. An urban background and the migration intention of our respondents increase the probability of intention to create a business. Most students involved in the cohort (69\%) come from rural areas, and $35 \%$ of them plan to be self-employed. In the case of urban students, $42 \%$ of them would like to have their own business. Our questionnaire does not include a question regarding the place of future work or the type of business establishment. Therefore, we do not know whether students who plan to be self-employed prefer to run their business in the city or rural areas, e.g., in their parental municipality. However, our previous research showed that only $17 \%$ of the rural respondents report the desire to return home after graduation (Bednaříková et al., 2016), and only a few of them are willing to run a business.

The perception that it is not difficult to establish a business in the parental municipality increases the probability of the intention to create a business in our model. $33.5 \%$ of respondents of rural origin perceive the establishment of a company as very difficult compared to $21.8 \%$ of respondents of urban origin. These results suggest that cities offer better conditions and more opportunities for running a business than rural areas. The most critical regional factors affecting entrepreneurial progress are difficulties in finding sufficiently skilled staff, poor state support for small enterprises, an adverse entrepreneurial climate, poor infrastructure, and low purchasing power of potential customers due to inadequate living standards (Kalugina, 2014; Korchagina, 2014). The idea that starting an own business is complicated may stem from the ignorance of this issue in education and policy. Universities in Altai Krai do not provide entrepreneurial education or any support for entrepreneurship (except the basic university courses in economics).

The negative factors might also explain our results, indicating that the attraction to rural life decreases the intention to be self-employed. Manokin (2012) shows that the work motivations of older generations, such as social protection, stability, and confidence in the future, are also characteristic of young people in rural areas.

Quality of life. The effect of three variables related to the quality of life was tested in the model. The increasing importance of salaries, increasing importance of career, and perception of leading a purposeful and meaningful life boost the probability of creating an own business.

Salaries from employment are generally quite low in Russia, so the expectation of increased earnings and financial security motivates the tendencies to found a business. This notion even outweighs the relative certainty of a regular monthly income and the uncertainty of a higher income from self-employment, especially in rural areas.

Experience in the labor market shows that, in the case of youth employment, employers are not always guided by the criteria of economic feasibility. The prevailing social traditions strongly influence them concerning young people and public opinions of the workforce and the stability of its position. These factors, together with economic factors, have led to intensified discrimination of young people on the labor market (Kasyanov, 2011). As the Russian social policy is characterized by the extreme pressure of old approaches and traditions (Kasyanov, 


\section{Agricultural and Resource Economics}

www.are-journal.com

2011), making a career through entrepreneurship might be the only possibility for the realization of employment activities and a job. The effort of individuals to live a purposeful life can serve as a conduit for increased entrepreneurial businesses through a belief in their capabilities.

Conclusions. Self-employment is of critical importance for the economic development of a region, especially for its rural and remote parts. This paper aimed to investigate factors that influence the intention of youth in remote areas of Siberia to start-up business under the specific conditions due to a post-communist legacy. Special attention was paid to the willingness of graduates to run a business in agriculture.

Study results revealed that being a male, an existing family entrepreneurial tradition, and an effort of respondents to increase their quality of life, such as the desire for a higher income and career efforts, increase the intention to be selfemployed. The intention to live in rural areas decreases the entrepreneurial intention. Regarding the family entrepreneurial tradition, we identified a vital path dependency problem that arises from the low entrepreneurial literacy and culture of the families because setting up a private business is a novelty in Russia.

The study showed that respondents who are attracted to rural life less intend to be self-employed than others, and one could expect them to be ready to embrace rural life such as it is. Even though Russian rural development policy is focused mainly on the development of agriculture and thus promotes farm establishment, most of our respondents - students at the Agricultural University - do not plan to run their business nor in agriculture neither in other sectors.

Besides, this study has important implications for rural development. Helping young people to earn a living through entrepreneurship can make a crucial contribution to decreasing unemployment, ensure the income of the rural population, and thus reduce poverty. Youth entrepreneurship is a key tool to develop human capital, use the economic potential of youth, and promote sustainable growth of rural areas. Increasing demand for recreation represents a significant business opportunity, especially for villages located close to cities. Rural folk, a unique landscape, and traditional methods of production may also give rise to entrepreneurial opportunities in Russian rural areas. Entrepreneurs in agriculture might help in re-cultivation of the abandoned land in Russian Siberia if the entrepreneurial education and incentives were appropriately set.

Finally, the results of our research provide significant implications for local policymakers and the educational system. To make the rural entrepreneurship more attractive, the improvement of institutional environment and conditions for small and medium businesses seems to be necessary. Universities may foster business intentions by designing and implementing entrepreneurial education. This might be effective, especially in a country with a short entrepreneurial tradition.

We are aware of the gap between self-employment intentions and de facto selfemployment. Studying de facto self-employment in further research would bring fascinating insights into understanding the factors that affect youth establishment of 


\section{Agricultural and Resource Economics}

www.are-journal.com

their own business.

\section{References}

1. Arenius, P. and Kovalainen, A. (2006), Similarities and Differences Across the Factors Associated with Women's Self-employment Preference in the Nordic Countries. International Small Business Journal, vol. 24(1), pp.31-59. https://doi.org/10.1177/0266242606059778.

2. Åslund, A. (2012), How entrepreneurship could be promoted after the collapse of socialist economic system. Journal of Asian Economics, vol. 23, pp. 157167. https://doi.org/10.1016/j.asieco.2011.09.003.

3. Audretsch, D. B. and Thurik, A. R. (2000), Capitalism and democracy in the 21st century: from managed to the entrepreneurial economy. Journal of Evolutionary Economics, vol. 10, pp. 17-34.

4. Autio, E., Keeley, R. H., Klofsten, M. and Ulfstedt, T. (1997), Entrepreneurial intent among students: testing an intent model in Asia, Scandinavia and USA, Frontiers of Entrepreneurship Research, Babson Conference Proceedings. Babson: Babson College, USA, available at: https://fusionmx.babson.edu/entrep/fer/papers97/autio/aut1.htm.

5. Bakulina, O. and Chernish, O. (2016), Common European system of values as the basis of the agricultural enterprises staff motivation. Agricultural and Resource Economics, vol. 2, no. 1, available at: http://are-journal.com.

6. Bednaříková, Z., Bavorová, M. and Ponkina, E. (2016), Migration motivation of agriculturally educated rural youth: the case of Russian Siberia. Journal of Rural Studies, vol. 45, pp. 99-111. https://doi.org/10.1016/j.jrurstud.2016.03.006.

7. Benneworth, P. (2004), In what sense 'regional development'? Entrepreneurship, underdevelopment and strong tradition in the periphery. Entrepreneurship and Regional Development, vol.16, pp.439-458. https://doi.org/10.1080/0898562042000249786.

8. Boden, Jr. R. (1999), Flexible working hours, family responsibilities, and female self-employment. American Journal of Economics and Sociology, vol. 58(1), pp. 71-83. https://doi.org/10.1111/j.1536-7150.1999.tb03285.x.

9. Carter, N., Williams, M. and Reynolds, P. D. (1997), Discontinuance among new firms in retail: the influence of initial resources, strategy, and gender. Journal of Business Venturing, vol. 12, pp. 125-145. https://doi.org/10.1016/S08839026(96)00033-X.

10. Davidson, P. (1995), Determinants of entrepreneurial intentions, Paper presented at the RENT IX Workshop, Piacenza, Italy, November 23-24.

11. Edelman, L. F., Manolova, T., Shirokova, G. and Tsukanova, T. (2016), The impact of family support on young entrepreneurs' start-up activities. Journal of Business Venturing, vol. 31(4), pp. 428-448. https://doi.org/10.1016/j.jbusvent.2016.04.003.

12. Ellman, M. (2003), Expectations and Reality: Reflections on a Decade of Agricultural Transformation in Transition, institutions, and the rural sector, ed. M. Spoor,Lexington Book, Oxford, UK. 


\section{Agricultural and Resource Economics}

www.are-journal.com

13. Evans, D. S. and Leighton, L. S. (1990), Small business formation by unemployed workers. Small Business Economics, vol. 2, pp. 319-330, available at: https://www.jstor.org/stable/40228659.

14. GEM (2014), Global Entrepreneurship Monitor. Global Report.

15. Ghulam, N. and Liñán, F. (2011), Graduate entrepreneurship in the developing world: intentions, education and development. Education + Training, vol. 53, pp. 325-334. https://doi.org/10.1108/00400911111147668.

16. GKS (2016), Average monthly nominal wages of full-time employees. Federal State Statistical Office of Russian Federation.

17. Hemmasi, M. and Prorok, C. V. (2002), Women's migration and quality of life in Turkey. Geoforum, vol. 33, pp. 399-411. https://doi.org/10.1016/S00167185(02)00020-9.

18. Iakovleva, T., Kolvereid, L. and Stephan, U. (2011), Entrepreneurial intentions in developing and developed countries. Edducation + Training, vol. 53(5), pp. 353-370. https://doi.org/10.1108/00400911111147686.

19. Kalugina, Z. I. (2014), Agricultural Policy in Russia: Global Challenges and the Via bility of Rural Comunities. International Journal of Sociology of Agriculture and Food, vol. 21(1), pp. 115-131.

20. Kasyanov, V. V. (2011), Market present and future of Russian youth. Obschestvo: sociologiya, psikhologiya, pedagogika vol. 3-4, pp. 11-13.

21. Kibler, E. (2013), Formation of entrepreneurial intentions in a regional context. Entrepreneurship \& Regional Development, vol. 25, pp. 293-323. https://doi.org/10.1080/08985626.2012.721008.

22. Kiryushin, P. (2011), Small and medium business in Russia. Journal of International Relation Theory and World Politics, vol. 9, no. 1(25), pp. 111-120.

23. Korchagina, I. A. (2014), Development of rural territories of the Altai region: problems and ways of solution. Science Time, vol. 7(7), pp. 179-187.

24. Kovalenko, E. G. (2012), The Mechanism of sustainable development of rural territories of the region. Sovremennye problemy nauki $i$ obrazovaniya, vol. 2, available at: https://science-education.ru/ru/article/view?id=5823.

25. Kozina, I. (2005), The significance of Gender Stereotypes in the Russian Labour Market in Gender Transitions in Russia and Eastern Europe, ed. I. A. Morell, H. Carlbäck, M. Hurd, S. Rastbäck. Gondolin, Eslöv, Sweden.

26. Laspita, S., Breugst, N., Heblich, S. and Patzelt, H. (2012), Intergenerational transmission of entrepreneurial intentions. Journal of Business Venturing, vol. 27, no. 4, pp. 414-435. https://doi.org/10.1016/j.jbusvent.2011.11.006.

27. Lehberger, M. and Hirschauer, N. (2015), Recruitment problems and the shortage of junior corporate farm managers in Germany: the role of gender-specific assessments and life aspirations. Agriculture and Human Values, vol. 33(3), pp. 611624. https://doi.org/10.1007/s10460-015-9637-4.

28. Ljubotina, P., Bojnec, Š. and Vadnjal, J. (2019), Macroeconomic factors forming family business heir's career choice intention. Acta Oeconomica, vol. 69(3), pp. 425-444. https://doi.org/10.1556/032.2019.69.3.5. 


\section{Agricultural and Resource Economics}

www.are-journal.com

29. Manokin, N. A. (2012), Young people in the labor market, work attitudes and preferences. Paper presented at the conference in Nauchno-izdatelskyy centr Sociosfera, Penza, Russia.

30. Manolova, T. S., Edelman, L. F., Shirokova, G. and Tsukanova, T. (2019), Youth entrepreneurship in emerging economies: can family support help navigate institutional voids? Journal of East-West Business vol. 25(4), pp. 363-395. https://doi.org/10.1080/10669868.2019.1624672.

31. Matthews, C. H. and Moser, S. B. (1995), Family Background and Gender: Implications for Interest in Small Firm Ownership. Entrepreneurship \& Regional Development, vol. 7(4), pp. 365-377.

32. Ministry of Education and Science (2014), Employment monitoring of graduates of the higher educational institutions. Ministry of Education and Science of the Russian Federation, Moscow, Russia, available at: http://vo.graduate.edu.ru.

33. Mueller, P. (2006), Entrepreneurship in the region: Breeding ground for nascent entrepreneurs? Small Business Economics vol.27, pp.41-58. https://doi.org/10.1007/s11187-006-6951-7.

34. Nabi, G., Holden, R. and Walmsley, A. (2010), From student to entrepreneur: Towards a model of graduate career-making in business start-up. Journal of Education and Work, vol. 23(5), pp. 389-415.

35. Naudé, W., Gries, T., Wood, E. and Meintjes, A. (2008), Regional determinants of entrepreneurial start-ups in a developing country. Entrepreneurship \& Regional Development, vol. 20, pp. 111-124. https://doi.org/10.1080/08985620701631498.

36. Noorderhaven, N., Thurik, R. and Wennekers, S. A. van Stel (2004), The Role of Dissatisfaction and Per Capita Income in Explaining Self-Employment across 15 European Countries. SCALES-paper N200407, Zoetermeer, Neetherlands.

37. Oinonen, E. (2018), Under pressure to become - from a student to entrepreneurial self. Journal of Youth Studies, vol.21(10), pp. 1344-1360. https://doi.org/10.1080/13676261.2018.1468022.

38. Poon, J. P. H., Thai, D. T. and Naybor, D. (2012), Social capital and female entrepreneurship in rural regions: Evidence from Vietnam. Applied Geography, vol. 35, pp. 308-315. https://doi.org/10.1016/j.apgeog.2012.08.002.

39. Rosstat (2007), Preliminary results of the All-Russia Agricultural Census 2006. Moscow, Federal Statistical Office, Russia.

40. RSPP (2016), O sostoyanii delovogo klimata v Rossii v 2015 godu rasshirennyy doklad. The Russian Union of Industrialists and Entrepreneurs, Moscow, Russia.

41. Sätre, A.-M. (2010), Women's Work in transitional Russia: Women's Strategies for Entrepreneurship and Survival in Russian Regions in Perestroika: Process and Consequences, eds. Kangaspurov, M., Nikula, J. and Stodolsky, I., Finnish Literary Society, Helsinki, Finland.

42. Scherer, R. F., Brodzinski, J. F. and Wiebe, F. A. (1990), Entrepreneur career selection and gender: a socialization approach. Journal of Small Business 


\section{Agricultural and Resource Economics}

www.are-journal.com

Management, vol. 2, pp. 37-44.

43. Scott, M. G. and Twomey, D. F. (1988), The long-term supply of entrepreneurs: students career aspirations in relation to entrepreneurship. Journal of Small Business Management, vol. 26(4), pp. 5-13.

44. Sergienko, A. M., Anisimova, M. M., Ivanova, O. A., Perekarenkova, Y. A., Rzaeva, S. V., Reshetnikova, S. A. and Rodionova, L. V. (2013), Bednost selskoy Rosii v usloviyach modernizacii ekonomiki: processy i mechanizmy formirovaniya i preodoleniya. AZBUKA, Barnaul, Russia.

45. Spoor, M. and Visser, O. (2001), The state of agrarian reform in the former Soviet Union. Europe-Asia Studies, vol. 53, pp. 885-901.

46. Stathopoulou, S., Psaltopoulos, D. and Skuras, D. (2004), Rural entrepreneurship in Europe - A research framework and agenda. International Journal of Entrepreneurial Behaviour and Research, vol. 10(6), pp. 404-425.

47. Strategy (2016), Strategiya ustoychivogo razvitiya selskikh territoriy Rossiyskoy Federacii na period do 2030 goda, No. 151-p. [Strategy of sustainable development of rural areas of the Russian Federation up to 2030], Moscow, Russia.

48. Sutherland, L. A. (2010), Differentiating farmers: opening the black box of private farming in post-Soviet states. Agricultural Human Values, vol. 27, pp. 259276.

49. Tkachev, A. and Kolvereid, L. (1999), Self-employment intentions among Russian students. Entrepreneurship \& Regional Development, vol. 11, pp. 269-280.

50. Turker, D., Onvural, B., Kursunluoglu, E. and Pinar, C. (2005), Entrepreneurial propensity: a field study on the Turkish university students. International Journal of Business, Economics and Management, vol. 1(3), pp. 15-27.

51. Turker, D., and Selcuk, S. S. (2008), Which factors affect entrepreneurial intention of university students? Journal of European Industrial Training, vol. 33(2), pp. 142-159.

52. Unay-Gailhard, İ. (2016), Job access after leaving education: a comparative analysis of young women and men in rural Germany. Journal of Youth Studies, vol. 19(10), pp. 1355-1381.

53. Utsch, A., Rauch, A., Rothfuss, R. and Frese, M. (1999), Who becomes a small-scale entrepreneur in a post-socialist environment: On the differences between entrepreneurs and managers in East Germany. Journal of Small Business Management, vol. 37(3), pp. 31-42.

54. Wang, C. K. and Wong, P. K. (2004), Entrepreneurial interest of university students in Singapore. Technovation, vol. 24(2), pp. 163-172.

55. Ylinenpää, H. and Chechurina, M. (2000), Perceptions of female entrepreneurship in Russia. Paper presented at EFMD $30^{\text {th }}$ Small Business Seminar in Ghent, Belgium. 


\section{Appendix}

Table A.1

\section{Descriptive statistics of dependent and independent variables used for logistic regression analysis of the entrepreneurship intentions of 470 students at the Altai State Agricultural University in Barnaul, Russia, 2014}

\begin{tabular}{|c|c|c|c|c|}
\hline \multirow[t]{2}{*}{ Question code } & \multirow[t]{2}{*}{ Question text } & \multirow[t]{2}{*}{ List of answers } & \multicolumn{2}{|c|}{$\begin{array}{c}\% \text { of respondents } \\
\text { (number) }\end{array}$} \\
\hline & & & Employee & Own business \\
\hline $\begin{array}{l}\text { Dependent variable: } \\
\text { Entrepreneurship } \\
\text { intention }\end{array}$ & $\begin{array}{l}\text { Do you plan to be an } \\
\text { employee or to establish } \\
\text { your own business? }\end{array}$ & $\begin{array}{l}0 \text { - employee } \\
1 \text { - establish a } \\
\text { business }\end{array}$ & $\begin{array}{l}62.77 \\
(295)\end{array}$ & $\begin{array}{l}37.23 \\
(175)\end{array}$ \\
\hline \multicolumn{5}{|c|}{ Personal and family background } \\
\hline $\begin{array}{l}\text { Gender (dummy } \\
\text { variable) }\end{array}$ & & $\begin{array}{l}1 \text { - male } \\
2 \text { - female }\end{array}$ & $\begin{array}{l}37.97 \\
62.03\end{array}$ & $\begin{array}{l}43.43 \\
56.57\end{array}$ \\
\hline $\begin{array}{l}\text { Father's education } \\
\text { (dummy) }\end{array}$ & $\begin{array}{l}\text { What is the highest } \\
\text { educational level } \\
\text { completed by your } \\
\text { father? }\end{array}$ & $\begin{array}{l}0 \text { - secondary } \\
\text { education } \\
0 \text { - secondary } \\
\text { technical education } \\
1 \text { - university }\end{array}$ & 69.15 & 68.00 \\
\hline $\begin{array}{l}\text { Mother's education } \\
\text { (dummy) }\end{array}$ & $\begin{array}{l}\text { What is the highest } \\
\text { educational level } \\
\text { completed by your } \\
\text { mother? }\end{array}$ & $\begin{array}{l}0 \text { - secondary } \\
\text { education } \\
0 \text { - secondary } \\
\text { technical education } \\
1 \text { - university }\end{array}$ & 43.39 & 61.14 \\
\hline $\begin{array}{l}\text { Father's employment } \\
\text { status (dummy) }\end{array}$ & $\begin{array}{l}\text { What is the } \\
\text { employment status of } \\
\text { your father? }\end{array}$ & $\begin{array}{l}0 \text { - business } \\
\text { employee } \\
0 \text { - civil servant } \\
0 \text { - unemployed } \\
1 \text { - self-employed }\end{array}$ & 11.53 & 25.14 \\
\hline $\begin{array}{l}\text { Mother's } \\
\text { employment status } \\
\text { (dummy) }\end{array}$ & $\begin{array}{l}\text { What is the } \\
\text { employment status of } \\
\text { your mother? }\end{array}$ & $\begin{array}{l}0 \text { - business } \\
\text { employee } \\
0 \text { - civil servant } \\
0 \text { - unemployed } \\
1 \text { - self-employed }\end{array}$ & 94.24 & 86.29 \\
\hline $\begin{array}{l}\text { Parents expect } \\
\text { support }\end{array}$ & $\begin{array}{l}\text { My parents hope I will } \\
\text { support them } \\
\text { financially in the future. }\end{array}$ & $\begin{array}{l}1 \text { - strongly } \\
\text { disagree } \\
2 \text { - disagree } \\
3 \text { - agree } \\
4 \text { - strongly agree }\end{array}$ & $\begin{array}{c}4.42 \\
26.19 \\
55.44 \\
13.95\end{array}$ & $\begin{array}{c}1.71 \\
23.43 \\
52.57 \\
22.29\end{array}$ \\
\hline \multicolumn{5}{|l|}{ Rurality } \\
\hline $\begin{array}{l}\text { Difficulty in creating } \\
\text { business }\end{array}$ & $\begin{array}{l}\text { Do you consider the } \\
\text { establishment of your } \\
\text { own business in the } \\
\text { parental municipality as } \\
\text { difficult? }\end{array}$ & $\begin{array}{l}1 \text { - yes, it is very } \\
\text { difficult } \\
2 \text { - yes, it is } \\
\text { difficult } \\
3 \text { - no, it is not } \\
\text { difficult }\end{array}$ & $\begin{array}{c}33.9 \\
59.32 \\
6.78\end{array}$ & $\begin{array}{c}24.0 \\
61.71 \\
14.29\end{array}$ \\
\hline
\end{tabular}




\section{Agricultural and Resource Economics}

www.are-journal.com

\begin{tabular}{|c|c|c|c|c|}
\hline \multicolumn{5}{|c|}{ Continuation of table A.1 } \\
\hline Place of origin & $\begin{array}{l}\text { Please indicate the } \\
\text { name and region of } \\
\text { your parental } \\
\text { municipality. }\end{array}$ & $\begin{array}{l}0 \text { - rural } \\
1 \text { - urban (Barnaul, } \\
\text { Rubcovsk, Bijsk, } \\
\text { Gorno Altaisk) }\end{array}$ & $\begin{array}{l}74.92 \\
25.08\end{array}$ & $\begin{array}{l}66.29 \\
33.71\end{array}$ \\
\hline Migration intention & $\begin{array}{l}\text { Do you want to migrate } \\
\text { out of your parental } \\
\text { municipality after } \\
\text { completing university? }\end{array}$ & $\begin{array}{l}1 \text { - sure not } \\
2 \text { - probably not } \\
3 \text { - probably yes } \\
4 \text { - sure yes }\end{array}$ & $\begin{array}{c}8.47 \\
13.22 \\
51.53 \\
26.78\end{array}$ & $\begin{array}{c}9.71 \\
10.86 \\
41.14 \\
38.29\end{array}$ \\
\hline Attracted to rural life & $\begin{array}{l}\text { Are you attracted to the } \\
\text { rural lifestyle? }\end{array}$ & $\begin{array}{l}1 \text { - no } \\
2 \text { - yes, if economic } \\
\text { and social } \\
\text { conditions are } \\
\text { satisfactory } \\
3 \text { - yes }\end{array}$ & $\begin{array}{l}26.53 \\
61.22\end{array}$ & $\begin{array}{c}33.91 \\
56.9\end{array}$ \\
\hline \multicolumn{5}{|l|}{ Quality of life } \\
\hline $\begin{array}{l}\text { Importance of wage } \\
\text { level }\end{array}$ & $\begin{array}{l}\text { How important is the } \\
\text { wage level for you? }\end{array}$ & $\begin{array}{l}1 \text { - unimportant } \\
2 \text { - less important } \\
3 \text { - important } \\
4 \text { - very important }\end{array}$ & $\begin{array}{c}1.02 \\
1.36 \\
31.86 \\
65.76\end{array}$ & $\begin{array}{c}1.71 \\
2.29 \\
27.43 \\
68.57\end{array}$ \\
\hline $\begin{array}{l}\text { Importance of career } \\
\text { opportunities }\end{array}$ & $\begin{array}{l}\text { How important are } \\
\text { carrier opportunities for } \\
\text { you? }\end{array}$ & $\begin{array}{l}1 \text { - unimportant } \\
2 \text { - less important } \\
3 \text { - important } \\
4 \text { - very important }\end{array}$ & $\begin{array}{c}1.36 \\
6.78 \\
41.02 \\
50.85\end{array}$ & $\begin{array}{c}0.57 \\
2.86 \\
30.29 \\
66.29\end{array}$ \\
\hline $\begin{array}{l}\text { Lead a meaningful } \\
\text { life }\end{array}$ & $\begin{array}{l}\text { To what extent do you } \\
\text { agree with the } \\
\text { following statement? } \\
\text { I lead a purposeful and } \\
\text { meaningful life. }\end{array}$ & $\begin{array}{l}1 \text { - strongly } \\
\text { disagree } \\
2 \text { - disagree } \\
3 \text { - undecided } \\
4 \text { - agree } \\
5 \text { - strongly agree }\end{array}$ & $\begin{array}{c}1.36 \\
2.04 \\
14.29 \\
62.93 \\
19.39\end{array}$ & $\begin{array}{c}0 \\
1.71 \\
10.29 \\
56.0 \\
32.0\end{array}$ \\
\hline
\end{tabular}

How to cite this article? Як цитувати цю статтю?

Стиль-ДСТУ:

Bednarikova Z., Bavorova M., Ponkina E. Entrepreneurial intention of agriculture undergraduates in Russia. Agricultural and Resource Economics. 2020. Vol. 6. No. 1. Pp. 5-22. URL: http://are-journal.com.

Style-Harvard:

Bednarikova, Z., Bavorova, M. and Ponkina, E. (2020), Entrepreneurial intention of agriculture undergraduates in Russia. Agricultural and Resource Economics, vol. 6, no. 1, pp. 5-22, available at: http://are-journal.com. 